\title{
Wildlife species, Ixodid fauna and new host records for ticks in an Amazon forest area, Rondônia, Brazil
}

\author{
Espécies de vida selvagem, fauna ixodídica e novos registros de hospedeiros de carrapatos \\ em uma área de Floresta Amazônica, Rondônia, Brasil
}

\author{
Namor Pinheiro Zimmermann ${ }^{1,2}$; André de Abreu Rangel Aguirre ${ }^{3,4}$; Vinicius da Silva Rodrigues ${ }^{1,3}$; \\ Marcos Valério Garcia ${ }^{1,5^{*}}$; Jansen Fernandes Medeiros ${ }^{4}$; Isabella Maiumi Zaidan Blecha ${ }^{1,6}$; Pamella Oliveira Duarte ${ }^{1,3}$; \\ Breno Cayeiro Cruz ${ }^{7}$; Rodrigo Casquero Cunha ${ }^{8}$; Thiago Fernandes Martins ${ }^{9}$; Renato Andreotti ${ }^{10}$ \\ ${ }^{1}$ Laboratório de Biologia do Carrapato, Embrapa Gado de Corte, Empresa Brasileira de Pesquisa Agropecuária - EMBRAPA, \\ Campo Grande, MS, Brasil \\ ${ }^{2}$ Centro Universitário da Grande Dourados, Dourados, MS, Brasil \\ ${ }^{3}$ Programa de Pós-Graduação em Doenças Infecciosas e Parasitárias, Universidade Federal de Mato Grosso do Sul - UFMS, \\ Campo Grande, MS, Brasil \\ ${ }^{4}$ Laboratório de Entomologia Médica, Fundaçáo Oswaldo Cruz - FIOCRUZ, Porto Velho, RO, Brasil \\ ${ }^{5}$ Programa de Desenvolvimento Científico Regional - DCR, Fundação de Apoio ao Desenvolvimento do Ensino, \\ Ciência e Tecnologia - FUNDECT, Governo do Estado de Mato Grosso do Sul, Campo Grande, MS, Brasil \\ ${ }^{6}$ Programa de Pós-Graduação em Ciência Animal, Universidade Federal de Mato Grosso do Sul - UFMS, Campo Grande, MS, Brasil \\ 7 Programa de Pós-Graduaçáo em Patologia Animal, Departamento de Patologia Veterinária, Faculdade de Ciências Agrárias e \\ Veterinárias - FCAV, Universidade Estadual Paulista - UNESP, Jaboticabal, SP, Brasil \\ ${ }^{8}$ Programa de Pós-Graduaçáo em Biotecnologia, Núcleo de Biotecnologia, Centro de Desenvolvimento Tecnológico - CDTec, \\ Universidade Federal de Pelotas - UFPEL, Pelotas, RS, Brasil \\ ${ }^{9}$ Departamento de Medicina Veterinária Preventiva e Saúde Animal, Faculdade de Medicina Veterinária e Zootecnia, \\ Universidade de São Paulo - USP, São Paulo, SP, Brasil \\ ${ }^{10}$ Embrapa Gado de Corte, Empresa Brasileira de Pesquisa Agropecuária - EMBRAPA, Campo Grande, MS, Brasil
}

Received October 27, 2017

Accepted March 03, 2018

\begin{abstract}
The objective of this work was to evaluate the diversity of ticks associated with free-living animals and to investigate new host records for ticks. Ticks were collected from animals rescued during the flood of the Jamari River in the municipality of Ariquemes, state of Rondônia, North Region of Brazil. A total of 39 animals were captured, out of which 10 were amphibians, 19 were reptiles and 10 were mammals. A total of 127 ticks of the Amblyomma genus were collected from these animals, distributed among seven species: Amblyomma dissimile, Amblyomma geayi, Amblyomma humerale, Amblyomma longirostre, Amblyomma nodosum, Amblyomma rotundatum and Amblyomma varium. In addition, one specimen of Rhipicephalus (Boophilus) microplus was collected. Among these specimens, 85 were adults and 42 were nymphs, with $A$. rotundatum being the most prevalent species. An Amblyomma spp. larvae was also collected from a lizard (Uranoscodon superciliosus), and one Amblyomma calcaratum and one Amblyomma dubitatum were recovered from the environment, thus totaling 130 ticks. Among the Ixodidae collected from different hosts, we provide the first report for the species A. rotundatum parasitizing Rhinella major, U. superciliosus, Leptophis ahaetulla, Chironius multiventris, and Mastigodryas boddaerti, as well as of $A$. humerale parasitizing $U$. superciliosus, A. geayi parasitizing Choloepus didactylus, and Rhipicephalus (B.) microplus parasitizing Alouatta puruensis.
\end{abstract}

Keywords: New hosts, tick fauna, wild animals.

\section{Resumo}

O objetivo deste trabalho foi avaliar a diversidade de carrapatos associados à animais de vida livre e investigar novos registros de hospedeiros. Coletas foram feitas em animais resgatados durante a cheia do Rio Jamari, localizado no município de Ariquemes, estado de Rondônia, Região Norte do Brasil. Um total de 39 animais foi capturado, dos quais dez eram

*Corresponding author: Marcos Valério Garcia. Laboratório de Biologia do Carrapato, Embrapa Gado de Corte, Campo Grande, MS, Brasil. e-mail: marcosvagar@gmail.com. anfíbios, 19 eram répteis e dez eram mamíferos. 127 carrapatos do gênero Amblyomma foram coletados destes animais, distribuídos em sete espécies: Amblyomma dissimile, Amblyomma geayi, 


\begin{abstract}
Amblyomma humerale, Amblyomma longirostre, Amblyomma nodosum, Amblyomma rotundatum e Amblyomma varium. Adicionalmente, um exemplar de Rhipicephalus (Boophilus) microplus foi coletado. Dentre estes espécimes, 85 eram adultos e 42 eram ninfas, com A. rotundatum sendo a espécie mais prevalente. Uma larva de Amblyomma spp. também foi coletada de um lagarto (Uranoscodon superciliosus), um Amblyomma calcaratum e um Amblyomma dubitatum foram recuperados do ambiente, assim totalizando 130 carrapatos. Dentre os ixodídeos coletados de diferentes hospedeiros, este trabalho fornece o primeiro registro da espécie A. rotundatum parasitando Rhinella major, U. superciliosus, Leptophis ahaetulla, Chironius multiventris e Mastigodryas boddaerti, assim como da espécie $A$. humerale parasitando U. superciliosus, a espécie A. geayi parasitando Choloepus didactylus e R. microplus parasitando Alouatta puruensis.
\end{abstract}

Palavras-chave: Novos hospedeiros, fauna ixodídica, animais selvagens.

\section{Introduction}

The Rondônia state, located in the North Region of Brazil, possesses wide reserves of natural Amazon forest, as well as many degraded areas. This state has been the focus of several tick-related studies, putting it in a prominent position since $34(52 \%)$ of the 65 species in the country had already been catalogued here by 2014 (MARTINS et al., 2014). However, the Amblyomma sculptum Berlese, 1888 species was recently reported for the first time in Rondônia, bringing the total to 35 species in the state (MARTINS et al., 2016). Although an already large number of Ixodidae species have been reported, that number will tend to increase due to new discoveries. Notably, reports regarding Brazilian tick fauna in recent years have been gradually increasing for both the Ixodidae and Argasidae families. Brazil today has 71 tick species, with 46 belonging to the Ixodidae family and 25 belonging to the Argasidae family (MARTINS et al., 2014, 2016; BARROS-BATTESTI et al., 2015; KRAWCZAK et al., 2015; LABRUNA et al., 2016; WOLF et al., 2016; MUÑOZ-LEAL et al. 2017).

Many of these ectoparasites have been getting closer to and interacting more frequently with domestic animals and, consequently, human beings. Because of this interaction, current research studies have focused on Ixodidae populations as well as their interaction with hosts and the environment since these ticks have the vectorial capacity to transmit agents that can cause diseases in human beings (LABRUNA et al., 2005, 2010; MARTINS et al., 2014).

Interventions in natural environments provide favorable conditions for infectious diseases due to both human interference, such as deforestation, and the constant changes made by man with the construction of roads, barrages, agriculture, and other activities (PATZ et al., 2004). Some tick species in Brazil, mainly from the Amblyomma genus, are pathogen vectors and are directly involved in the transmission of infectious agents to human beings, including spotted fever (Brazilian Spotted Fever) caused by bacteria of the genus Rickettsia (LABRUNA et al., 2011; OGRZEWALSKA \& PINTER, 2016).

The objective of this study was to identify the tick fauna on wild animals captured in a degraded area and to investigate new records of tick-host relationships.

\section{Material and Methods}

\section{Location and period of collection}

The capture of hosts was performed during the rescue of wild animals from the flood of the Jamari River after the construction of the Jamari Hydroelectric Central (PCH - Jamari) $\left(10^{\circ} 53^{\prime} 7^{\prime \prime} \mathrm{S}\right.$ and $61^{\circ} 57^{\prime} 6$ " W), located in the municipality of Ariquemes, state of Rondônia, North Region of Brazil. The captures started in the beginning of November 2014 and lasted until February 2015.

\section{Animal capture}

All animals were captured and physically contained according to the methods in Rodrigues et al. (2016) before being transported to the wild animal triage center located near PCH - Jamari. The animal capture, triage, and translocation were executed by a team hired for the task and composed of field workers, biologists and veterinarians with the necessary technical abilities. During triage, each animal was identified by species, sex and weight. Afterwards, tick collections were performed.

\section{Collection, identification and processing of ticks}

Ticks were collected during the clinical examination and inspection of captured animals. The parasites were removed from hosts by holding ticks by their bodies and applying force against the host, turning the tick body $90^{\circ}$ until the hypostome was completely removed from the skin. Afterwards, they were put in plastic receptacles with pierced covers for subsequent identification.

Later, the ticks were taken to the laboratory and identified with a stereomicroscope using dichotomous keys from Onofrio et al. (2006) for adults and Martins et al. (2010) for nymphs. For confirmation of the species, the Amblyomma humerale Koch, 1844 nymph was subjected to DNA extraction and sequencing, as this specimen had breakdowns that made identification by dichotomous key difficult. The ticks were deposited into the collection of the Tick Laboratory, Embrapa Gado de Corte, Campo Grande, Mato Grosso do Sul, Brazil. (Access numbers: 28-30, 35).

\section{DNA extraction, PCR and sequencing}

Tick DNA was extracted using a protocol based on guanidine isothiocyanate and phenol/chloroform extraction (SANGIONI et al., 2005 - adapted). The DNA was quantified with a spectrophotometer, and its integrity was verified by agarose gel electrophoresis at $0.8 \%$.

PCR using a $16 \mathrm{~S}$ rDNA primer for molecular identification of the $A$. humerale species was performed according to Mangold et al. (1998).

The product was analyzed on a $1.5 \%$ agarose gel, stained with ethidium bromide, visualized, and photographed under ultraviolet light exposure. 
Purification of the amplified fragment was done using the PureLink kit (Invitrogen). The fragment was cloned in a pGEM ${ }^{\circledR}$ T-Easy (Promega) vector and sequenced using the Sanger method (SANGER et al., 1977) with an ABI 3130 Genetic Analyzer (Applied Biosystems ${ }^{\circledR}$ ) for species verification.

Sequencing analysis was obtained with the Geneious Pro 4.8.5 software. Sequence similarity of the obtained sequence was compared using BLAST (NCBI, 2017).

All amplicons were sequenced, and individual sequences were aligned with each other and with the corresponding Amblyomma sequences available in GenBank using the BioEdit Sequence Alignment Editor (HALL, 1999) with the CLUSTAL W program (THOMPSON et al., 1994). Pair-wise comparisons of sequences were made using MEGA version 5 (TAMURA et al., 2011). Phylogenetic relationships were then explored in terms of neighbor-joining distances (NJ). An NJ tree was generated using the Tamura-Nei model with any gaps in the pair-wise comparisons excluded, and support for the NJ topology was tested by bootstrapping over 1,000 replications.

\section{Results}

A total of 39 animals were captured (Table 1), including 10 amphibians (eight Rhinella marina, and two Rhinella major), 19 reptiles (14 Uranoscodon superciliosus, as well as Bothrops atrox, Leptophis ahaetulla, Chironius multiventris, Mastigodryas boddaerti and Boa constrictor species, with one specimen each) and 10 mammals (three specimens of Choloepus hoffmanni and three Choloepus didactylus, two specimens of Tamandua tetradactyla, and one specimen each of Coendou prehensilis and Alouatta puruensis). A total of 127 ticks from the Amblyomma genus were collected from these animals, distributed among seven species (disregarding one
Amblyomma larva, the species of which could not be identified): Amblyomma dissimile Koch, 1844, Amblyomma geayi Neumann, 1899, A. humerale, Amblyomma longirostre (Koch, 1844), Amblyomma nodosum Neumann, 1899, Amblyomma rotundatum Koch, 1884 and Amblyomma varium Koch, 1844. Additionally, one specimen of Rhipicephalus (Boophilus) microplus (Canestrini, 1888) was also collected.

During the field activities, the authors found one specimen of Amblyomma calcaratum Neumann, 1899 and one of Amblyomma dubitatum Neumann, 1899 in free-living stages in the environment. A total of 87 adult ticks (10 males and 77 females), 42 nymphs and one larva were collected. Among the nymphs, only one was from the $A$. humerale species, while the rest were $A$. rotundatum. Among adults, the most abundant species was $A$. rotundatum, with 59 specimens, followed by $A$. nodosum, A. geayi, $A$. longirostre and $A$. varium, with 13 , five, three and three samples each, respectively. Only one specimen of $A$. calcaratum, one $A$. dissimile, one $A$. dubitatum, and one $R$. (B.) microplus were present, reaching a total of 130 specimens (Table 1 ).

The present study reports, for the first time, the parasitism by $A$. rotundatum of $R$. major, $U$. superciliosus, L. ahaetulla, $C$. multiventris and $M$. boddaerti, as well as $A$. humerale parasitizing $U$. superciliosus, A. geayi parasitizing $C$. didactylus, and $R$. (B.) microplus parasitizing $A$. puruensis.

BLAST analysis showed that the obtained $A$. humerale DNA sequence is close (99\% identity) to the corresponding sequence of A. humerale from the state of Amazonas, North Region of Brazil (GQ891952), as well as 95\% similar to the Amblyomma sabanerae Stoll, 1894 sequence from Costa Rica (KF702455), as illustrated in Figure 1.

Phylogenetic analysis indicated that the specimens collected from Amazon forest area, Rondônia, Brazil, correspond to $A$. humerale

Table 1. Number, instars and tick species identification include of the genera Amblyomma and Rhipicephalus collected from wild animals rescued from a forest area in the municipality of Ariquemes, Rondônia, Brazil.

\begin{tabular}{|c|c|c|}
\hline Species of captured animals & Number of captured animals & Tick species \\
\hline \multicolumn{3}{|l|}{ Amphibians } \\
\hline Rhinella marina & 8 & $27 \mathrm{~N}$ and $50 \mathrm{~F}$ A. rotundatum \\
\hline Rhinella major & 2 & 2F $A$. rotundatum \\
\hline \multicolumn{3}{|l|}{ Reptiles } \\
\hline Uranoscodon superciliosus & 14 & 1L Amblyomma spp.; 7N and 6F A. rotundatum; $1 \mathrm{~N}$ A. humerale \\
\hline Bothrops atrox & 1 & $1 \mathrm{~F}$ A. rotundatum \\
\hline Leptophis ahaetulla & 1 & $3 \mathrm{~N} A$. rotundatum \\
\hline Chironius multiventris & 1 & $3 \mathrm{~N} A$. rotundatum \\
\hline Mastigodryas boddaerti & 1 & $1 \mathrm{~N} A$. rotundatum \\
\hline Boa constrictor & 1 & 1F A. dissimile \\
\hline \multicolumn{3}{|l|}{ Mammals } \\
\hline Choloepus hoffmanni & 3 & $1 \mathrm{~F}$ and $1 \mathrm{M}$ A. geayi; $1 \mathrm{~F}$ A. varium \\
\hline Choloepus didactylus & 3 & $1 \mathrm{M}$ and $2 \mathrm{~F}$ A. geayi $1 \mathrm{M}$ and $1 \mathrm{~F}$ A. varium \\
\hline Tamandua tetradactyla & 2 & $4 \mathrm{M}$ and $9 \mathrm{~F}$ A. nodosum \\
\hline Coendou prehensilis & 1 & 3M A. longirostre \\
\hline Alouatta puruensis & 1 & 1F R. (B.) microplus \\
\hline Free-living stages & - & 1F A. calcaratum; $1 \mathrm{~F}$ A. dubitatum \\
\hline Total & 39 & 130 \\
\hline
\end{tabular}

M male; F female; N nymph; L larva. 


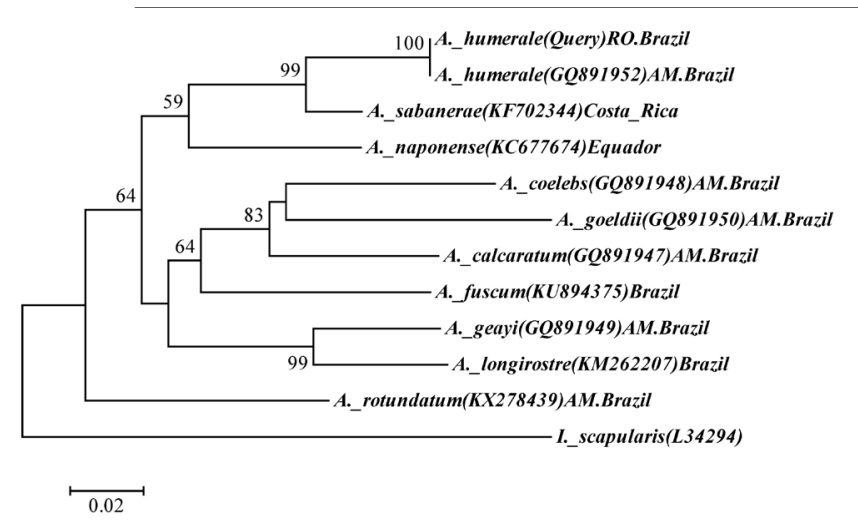

Figure 1. Neighbor-joining (NJ) tree built from Amblyomma humerale $16 \mathrm{~S}$ rDNA sequence collected in the municipality of Ariquemes, Rondônia, Brazil. The numbers represent the identity generated from 1,000 repetitions. These were used when identity is $>50 \%$. The Ixodes scapularis Say, 1821 sequence was used as an external group (out group).

(Figure 1). The Amazonian specimens clustered with sequences from Amazonas, Brazil, which may correspond to the geographic area of $A$. humerale, and is located closed to Rondonia, sharing the Amazon rainforest.

\section{Discussion}

Amblyomma rotundatum ticks were present on all captured species of amphibians and reptiles, with reports of nymph and adult instars; however, only females were found among the adults. This is due to the characteristic fact that this species parasitizes different cold-blooded hosts and reproduces through parthenogenesis, despite the presence of a male specimen on a Tropidurus sp. lizard and another one on a B. constrictor snake (ARAGÃO, 1936; LABRUNA et al., 2005; MARTINS et al., 2014).

Witter et al. (2016) reported $A$. rotundatum on $R$. marina and $B$. atrox in the state of Mato Grosso; however, according to Guglielmone \& Nava (2010), this tick species has never been reported on $R$. major, $U$. superciliosus, L. ahaetulla, C. multiventris or $M$. boddaerti. Therefore, this study reports, for the first time, these new hosts for the $A$. rotundatum species.

Among reptiles, the presence of $A$. dissimile on $B$. constrictor was also reported. Similar results were obtained by Fiorini et al. (2014) and Witter et al. (2016), who reported this tick species parasitizing B. constrictor. Amblyomma dissimile ticks are known to prefer parasitizing reptiles (BARROS-BATTESTI et al., 2006; SCOFIELD et al., 2011).

This study reports, for the first time in Brazil, an $A$. humerale tick parasitizing a lizard of the $U$. superciliosus species, with the A. humerale nymph identified morphologically and then confirmed through DNA extraction and sequencing. A clade was demonstrated a posteriori, with a $100 \%$ probability, between $A$. humerale (Query) RO, Brazil and $A$. humerale (GQ891952), within the phylogenetic tree. Amblyomma sabaranae from Costa Rica, showed 99\% of similarity with the $A$. humerale clade demonstrated in this study
(Figure 1). The other clades did not demonstrate any similarity with $A$. humerale species.

Labruna et al. (2002a) described the presence of $A$. humerale nymphs on Plica plica and Plica umbra lizards belonging to the Tropiduridae family, which is the same family to which $U$. superciliosus belongs, and Kentropyx calcarata, belonging to the Teiidae family, captured along the same river featured in this study. Labruna et al. (2002a) also described for the first time the presence of $A$. humerale in the state of Rondônia, as well as immature stages parasitizing a variety of small vertebrates.

Adult $A$. varium and $A$. geayi ticks found parasitizing sloths (C. hoffmanni and $C$. didactylus) in this study are associated primarily with the Xenarthra order, according to Marques et al. (2002) and Labruna et al. (2009). However, the first report of $A$. geayi parasitism on $C$. didactylus was made in this study, since descriptions of this tick species on sloths refer to the C. hoffmanni, Bradypus tridactylus, and Bradypus variegatus species (FAIRCHILD et al., 1966; LABRUNA et al., 2009; MARTINS et al., 2013).

Amblyomma nodosum adult ticks were found parasitizing T. tetradactyla. This tick species, when in its adult phase, prefers mammals from the Xenarthra order, which includes this host species. However, immature phases are involved in bird parasitism (GUIMARĀES et al., 2001; BARROS-BATTESTI et al., 2006). Witter et al. (2016) noted the presence of $A$. nodosum on free T. tetradactyla individuals. Different research studies have also reported adult $A$. nodosum present on T. tetradactyla (GARCIA et al., 2013; MARTINS et al., 2014).

Parasitism by $A$. longirostre adults is commonly associated with some Coendou species (GUIMARÁES et al., 2001), such as Coendou prehensilis, as registered in this study. Immature phases of $A$. longirostre are usually associated with bird parasitism (OGRZEWALSKA \& PINTER, 2016).

This is also the first report of an $R$. (B.) microplus semi-engorged female parasitizing an $A$. puruensis. This possibly occurred accidentally, since this female tick was attached to a young $A$. puruensis found separated from its mother and on the ground, where it possibly contacted $R$. (B.) microplus. Other Ixodidae species, especially Amblyomma sp. ticks, were reported parasitizing animals of the Alouatta genus (LABRUNA et al., 2002b; MARTINS et al., 2006; LAVINA et al., 2011; MARTINS et al., 2013, 2015). Labruna et al. (2002b) also rescued animals from the flood caused by the construction of the Porto Primavera hydroelectric plant and reported the presence of $18 \mathrm{~A}$. sculptum nymphs parasitizing three Alouatta caraya.

Other studies have reported the presence of $A$. aureolatum (Pallas, 1772) on Alouatta guariba specimens (MARTINS et al., 2006), A. aureolatum and A. ovale Kock, 1844 on Alouatta clamitans (LAVINA et al., 2011) and parasitism by $A$. parkeri Fonseca e Aragão, 1952 and $A$. sculptum nymphs of $A$. guariba (MARTINS et al., 2013, 2015). As observed in the present study, which reported a young debilitated animal on the ground, other studies show that parasitism by Ixodidae of primates of the Alouatta genus are usually associated with the presence of stressful conditions for these animals, either because they are hurt, young, or due to their permanent residence on the ground caused by some physical debility (MARTINS et al., 2006; LAVINA et al., 2011; MARTINS et al., 2015). 
This study observed and presented Ixodidae fauna parasitizing several animal species in a region of the state of Rondônia, in the North Region of Brazil. Amblyomma rotundatum was described, for the first time, parasitizing amphibians and reptiles of the $R$. major, $U$. superciliosus, L. ahaetulla, $C$. multiventris and $M$. boddaerti species. Also unprecedented were the parasitism reports of $A$. humerale on $U$. superciliosus lizards, $A$. geayi on $C$. didactylus sloths, and $R$. (B.) microplus on $A$. puruensis monkeys.

\section{Acknowledgements}

The research was supported by Coordenação de Aperfeiçoamento de Pessoal de Nível Superior - CAPES, Conselho Nacional de Desenvolvimento Científico e Tecnológico - CNPq, Fundação de Apoio ao Desenvolvimento do Ensino, Ciência e Tecnologia do Estado de Mato Grosso do Sul - FUNDECT-MS, Governo do Estado de Mato Grosso do Sul, Fundação de Amparo a Pesquisa do Estado de Rondônia - FAPERO-RO and Fiocruz - Rondônia.

\section{References}

Aragão H. Ixodidas brasileiros e de alguns paizes limitrophes. Mem Inst Oswaldo Cruz 1936; 31(4): 759-843. http://dx.doi.org/10.1590/S007402761936000400004 .

Barros-Battesti DM, Arzua M, Bechara GH. Carrapatos de importância médico-veterinária da Região Neotropical: Um guia ilustrado para identificação de espécies. São Paulo: Vox; International Consortium on Ticks and Tickborne Diseases (ICTTD-3); Butantan; 2006.

Barros-Battesti DM, Landulfo GA, Luz HR, Marcili A, Onofrio VC, Famadas KM. Ornithodoros faccinii n. sp. (Acari: Ixodida: Argasidae) parasitizing the frog Thoropa miliaris (Amphibia: Anura: Cycloramphidae) in Brazil. Parasit Vectors 2015; 8(1): 268. http://dx.doi.org/10.1186/ s13071-015-0877-3. PMid:25963542.

Fairchild GB, Kohls GM, Tipton V. The ticks of Panama. In: Wenzel RL, Tipton VJ. Ectoparasites of Panama. Chicago: The Field Museum; 1966. p. 167-219.

Fiorini LC, Craveiro AB, Mendes MC, Chiesorin Neto L, Silveira RD. Morphological and molecular identification of ticks infesting Boa constrictor (Squamata, Boidae) in Manaus (Central Brazilian Amazon). Rev Bras Parasitol Vet 2014; 23(4): 539-542. http://dx.doi.org/10.1590/ S1984-29612014084. PMid:25517537.

Garcia MV, Silva DC, Almeida RFC, Cunha RC, Matias J, Barros JC, et al. Environmentally associated ticks (Acari: Ixodidae) in Campo Grande, Mato Grosso do Sul, Brazil. Rev Bras Parasitol Vet 2013; 22(1): 124-128. http://dx.doi.org/10.1590/S1984-29612013000100023. PMid:24252958.

Guglielmone AA, Nava S. Hosts of Amblyomma dissimile Koch, 1844 and Amblyomma rotundatum Koch, 1844 (Acari: Ixodidae). Zootaxa 2010; 2541: 27-49.

Guimarães JC, Tucci EC, Barros-Batestti DM. Ectoparasitos de importância veterinária. São Paulo: Plêiade; 2001.

Hall TA. BioEdit: a user friendly biological sequence alignment editor and analysis program for Windows 95/98/NT. Nucleic Acids Symp Ser 1999; 41: 95-98.
Krawczak FS, Martins TF, Oliveira CS, Binder LC, Costa FB, Nunes $\mathrm{PH}$, et al. Amblyomma yucumense n. sp. (Acari: Ixodidae), a Parasite of Wild Mammals in Southern Brazil. J Med Entomol 2015; 52(1): 28-37. http://dx.doi.org/10.1093/jme/tju007. PMid:26336277.

Labruna MB, Barbieri FS, Martins TF, Brito LG, Ribeiro FDS. New tick records in Rondônia, Western Brazilian Amazon. Rev Bras Parasitol Vet 2010; 19(3): 192-194. http://dx.doi.org/10.1590/S1984-29612010000300014. PMid:20943027.

Labruna MB, Camargo LMA, Terrassini FA, Schumaker TTS, Camargo EP. Notes on parasitism by Amblyomma humerale (Acari: Ixodidae) in the state of Rondônia, Western Amazon, Brazil. J Med Entomol 2002a; 39(6): 814-817. http://dx.doi.org/10.1603/0022-2585-39.6.814. PMid:12495177.

Labruna MB, MattarV S, et al. Rickettsioses in Latin America, Caribbean, Spain and Portugal. Rev Mvz Cordoba 2011; 16(2): 2435-2457. http:// dx.doi.org/10.21897/rmvz.282.

Labruna MB, Nava S, Marcili A, Barbieri AR, Nunes PH, Horta $\mathrm{MC}$, et al. A new argasid tick species (Acari: Argasidae) associated with the rock cavy, Kerodon rupestris Wied-Neuwied (Rodentia: Caviidae), in a semiarid region of Brazil. Parasit Vectors 2016; 9(1): 511. http://dx.doi. org/10.1186/s13071-016-1796-7. PMid:27655282.

Labruna MB, Onofrio VC, Beati L, Arzua M, Bertola PB, Ribeiro AF, et al. Redescription of the female, description of the male, and several new records of Amblyomma parkeri (Acari:Ixodidae), a South American tick species. Exp ApplAcarol 2009; 49(3): 243-260. http://dx.doi.org/10.1007/ s10493-009-9257-z. PMid:19241123.

Labruna MB, Paula CD, Lima TF, Sana DA. Ticks (Acari: Ixodidae) on wild animals from the Porto-Primavera hydroelectric power station area, Brazil. Mem Inst Oswaldo Cruz 2002b; 97(8): 1133-1136. http://dx.doi. org/10.1590/S0074-02762002000800012. PMid:12563479.

Labruna MB, Terrassini FA, Camargo LMA. First report of the male of Amblyomma rotundatum (Acari: Ixodidae) from a field-collected host. J Med Entomol 2005; 42(6): 945-947. http://dx.doi.org/10.1093/ jmedent/42.6.945. PMid:16465732.

Lavina MS, Souza AP, Souza JC, Bellato V, Sartor AA, Moura AB. Ocorrência de Amblyomma aureolatum (Pallas, 1772) e A. ovale (Kock, 1844) (Acari: Ixodidae) parasitando Alouatta clamitans Cabrera, 1940 (Primates: Atelidae) na regiáo norte do estado de Santa Catarina. Arq Bras Med Vet Zootec 2011; 63(1): 266-269. http://dx.doi.org/10.1590/ S0102-09352011000100040.

Mangold AJ, Bargues MD, Mas-Coma S. Mitochondrial 16S rDNA sequences and phylogenetic relationships of species of Rhipicephalus and other tick genera among Metastriata (Acari: Ixodidae). Parasitol Res 1998; 84(6): 478-484. http://dx.doi.org/10.1007/s004360050433. PMid:9660138.

Marques S, Barros-Battesti DM, Faccini JLH, Onofrio VC. Brazilian distribution of Amblyomma varium Koch, 1844 (Acari: Ixodidae), a common parasite of sloths (Mammalia: Xenarthra). Mem Inst Oswaldo Cruz 2002; 97(8): 1141-1146. http://dx.doi.org/10.1590/S007402762002000800014. PMid:12563481.

Martins JR, Salomão EL, Doyle RL, Teixeira MC, Onofrio VC, BarrosBattesti DM. First record of Amblyomma aureolatum (Pallas, 1772) (Acari: Ixodidae) parasitizing Alouatta guariba (Humboldt, 1812) (Primata: Atelidae) in Southern Brazil. Rev Bras Parasitol Vet 2006; 15(4): 203205. PMid:17196126.

Martins TF, Barbieri ARM, Costa FB, Terassini FA, Camargo LMA, Peterka CRL, et al. Geographical distribution of Amblyomma cajennense 
(sensu lato) ticks (Parasitiformes: Ixodidae) in Brazil, with description of the nymph of $A$. cajennense (sensu stricto). Parasit Vectors 2016; 9(1): 186. http://dx.doi.org/10.1186/s13071-016-1460-2. PMid:27036324.

Martins TF, Onofrio VC, Barros-Battesti DM, Labruna MB. Nymphs of the genus Amblyomma (Acari: Ixodidae) of Brazil: descriptions, redescriptions, and identification key. Ticks Tick Borne Dis 2010; 1(2): 75-99. http://dx.doi.org/10.1016/j.ttbdis.2010.03.002. PMid:21771514.

Martins TF, Scofield A, Oliveira WB, Nunes PH, Ramirez DG, BarrosBattesti DM, et al. Morphological description of the nymphal stage of Amblyomma geayi and new nymphal records of Amblyomma parkeri. Ticks Tick Borne Dis 2013; 4(3): 181-184. http://dx.doi.org/10.1016/j. ttbdis.2012.11.015. PMid:23414796.

Martins TF, Teixeira RHF, Labruna MB. Occurrence of ticks on wild animals received and attended at the Parque Zoológico Municipal Quinzinho de Barros, Sorocaba, São Paulo, Brazil. Braz J Vet Res Anim Sci 2015; 52(4): 319-324. http://dx.doi.org/10.11606/issn.1678-4456. v52i4p319-324.

Martins TF, Venzal JM, Terassini FA, Costa FB, Marcili A, Camargo LMA, et al. New tick records from the state of Rondônia, western Amazon, Brazil. Exp Appl Acarol 2014; 62(1): 121-128. http://dx.doi. org/10.1007/s10493-013-9724-4. PMid:23975565.

Muñoz-Leal S, Toledo LF, Venzal JM, Marcili A, Martins TF, Acosta ICL, et al. Description of a new soft tick species (Acari: Argasidae: Ornithodoros) associated with stream-breeding frogs (Anura: Cycloramphidae: Cycloramphus) in Brazil. Ticks Tick Borne Dis 2017; 8(5): 682-692. http:// dx.doi.org/10.1016/j.ttbdis.2017.04.015. PMid:28506539.

National Center for Biotechnology Information - NCBI. BLAST: Basic Local Alignment Search Tool [online]. Rockville: Bethesda Softworks; 2017 [cited 2017 Out 27]. Available from: https://blast.ncbi.nlm.nih. gov/Blast.cgi

Ogrzewalska M, Pinter A. Ticks (Acari: Ixodidae) as ectoparasites of Brazilian wild birds and their association with rickettsial diseases. Braz J Vet Res Anim Sci 2016; 53(1): 1-31. http://dx.doi.org/10.11606/ issn.1678-4456.v53i1p1-31.

Onofrio VC, Labruna MB, Pinter A, Giacomin FG, Barros-Battesti DM. Comentários e chaves para as espécies do gênero Amblyomma. In: Barros-Battesti DM, Arzua M, Bechara GH. Carrapatos de importância médico-veterinária da Regiāo Neotropical: Um guia ilustrado para identificação de espécies. São Paulo: Vox; International Consortium on Ticks and Tickborne Diseases (ICTTD-3); Butantan; 2006. p. 53-113.
Patz JA, Daszak P, Tabor PDGM, Aguirre AA, Pearl M, Epstein J, et al., and the Working Group on Land Use Change and Disease Emergence. Unhealthy landscapes: policy recommendations on land use change and infectious disease emergence. Environ Health Perspect 2004; 112(10): 1092-1098. http://dx.doi.org/10.1289/ehp.6877. PMid:15238283.

Rodrigues VS, Zimmermann NP, Garcia MV, Pina FTB. Métodos de contençấo de animais para coleta de carrapatos. In: Andreotti R, Koller WW, Garcia MV. Carrapatos: Protocolos e técnicas para estudo. Brasília: Embrapa; 2016. p. 35-58.

Sanger F, Nicklen S, Coulson AR. DNA sequencing with chain-terminating inhibitors. Proc Natl Acad Sci USA 1977; 74(12): 5463-5467. http:// dx.doi.org/10.1073/pnas.74.12.5463. PMid:271968.

Sangioni LA, Horta MC, Vianna MCB, Gennari SM, Soares RM, Galvão MAM, et al. Rickettsial infection in animals and Brazilian spotted fever endemicity. Emerg Infect Dis 2005; 11(2): 265-270. http://dx.doi. org/10.3201/eid1102.040656. PMid:15752445.

Scofield A, Bahia M, Martins AL, Góes-Cavalcante G, Martins TF, Labruna MB. Amblyomma dissimile Koch (Acari: Ixodidae) attacking Primolius maracana Vieillot (Psittaciformes: Psittacidae) in the Amazon Region, State of Pará, Brazil. Neotrop Entomol 2011; 40(4): 509-511. http://dx.doi.org/10.1590/S1519-566X2011000400017. PMid:21952971.

Tamura K, Peterson D, Peterson N, Stecher G, Nei M, Kumar S. MEGA5: Molecular Evolutionary Genetics Analysis using maximum likelihood, evolutionary distance, and maximum parsimony methods. Mol Biol Evol 2011; 28(10): 2731-2739. http://dx.doi.org/10.1093/molbev/msr121. PMid:21546353.

Thompson JD, Higgins D, Gibson TJ. CLUSTAL W: improving the sensitivity of progressive multiple sequence alignment through sequence weighting, position-specific gap penalities and weight matrix choice. Nucleic Acids Res 1994; 22(22): 4673-4680. http://dx.doi.org/10.1093/ nar/22.22.4673. PMid:7984417.

Witter R, Martins TF, Campos AK, Melo ALT, Corrêa SHR, Morgado $\mathrm{TO}$, et al. Rickettsial infection in ticks (Acari: Ixodidae) of wild animals in midwestern Brazil. Ticks Tick Borne Dis 2016; 7(3): 415-423. http:// dx.doi.org/10.1016/j.ttbdis.2015.12.019. PMid:26775021.

Wolf RW, Aragona M, Muñoz-Leal S, Pinto LB, Melo ALT, Braga IA, et al. Novel Babesia and Hepatozoon agents infecting non-volant small mammals in the Brazilian Pantanal, with the first record of the tick Ornithodoros guaporensis in Brazil. Ticks Tick Borne Dis 2016; 7(3): 449-456. http:// dx.doi.org/10.1016/j.ttbdis.2016.01.005. PMid:26782931. 